\title{
An investigation into the effect of leadership style on stress-related presenteeism in South African knowledge workers
}

\begin{tabular}{|c|c|}
\hline \multicolumn{2}{|c|}{$\begin{array}{l}\text { Authors: } \\
\text { Reuben George }^{1} \\
\text { Manoj Chiba }{ }^{1} \text { (D) } \\
\text { Caren B. Scheepers }{ }^{1} \text { (D) }\end{array}$} \\
\hline \multicolumn{2}{|c|}{$\begin{array}{l}\text { Affiliations: } \\
{ }^{1} \text { Gordon Institute of Business } \\
\text { Science, University of } \\
\text { Pretoria, South Africa }\end{array}$} \\
\hline \multicolumn{2}{|c|}{$\begin{array}{l}\text { Corresponding author: } \\
\text { Caren Scheepers, } \\
\text { scheepersc@gibs.co.za }\end{array}$} \\
\hline \multicolumn{2}{|c|}{$\begin{array}{l}\text { Dates: } \\
\text { Received: } 07 \text { Sept. } 2015 \\
\text { Accepted: } 20 \text { Jan. } 2017 \\
\text { Published: } 28 \text { Mar. } 2017\end{array}$} \\
\hline \multicolumn{2}{|c|}{$\begin{array}{l}\text { How to cite this article: } \\
\text { George, R., Chiba, M., \& } \\
\text { Scheepers, C.B. (2017). An } \\
\text { investigation into the effect } \\
\text { of leadership style on } \\
\text { stress-related presenteeism } \\
\text { in South African knowledge } \\
\text { workers. SA Journal of } \\
\text { Human Resource } \\
\text { Management/SA Tydskrif vir } \\
\text { Menslikehulpbronbestuur, } \\
\text { 15(0), a754. https://doi. } \\
\text { org/10.4102/sajhrm. } \\
\text { v15i0.754 }\end{array}$} \\
\hline \multicolumn{2}{|c|}{$\begin{array}{l}\text { Copyright: } \\
\text { C 2017. The Authors. } \\
\text { Licensee: AOSIS. This work } \\
\text { is licensed under the } \\
\text { Creative Commons } \\
\text { Attribution License. }\end{array}$} \\
\hline \multicolumn{2}{|l|}{ Read online: } \\
\hline 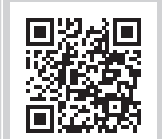 & $\begin{array}{l}\text { Scan this QR } \\
\text { code with your } \\
\text { smart phone or } \\
\text { mobile device } \\
\text { to read online. }\end{array}$ \\
\hline
\end{tabular}

Orientation: Leadership styles influence knowledge workers' job-stress-related presenteeism (JSRP) and, ultimately, organisational performance. Knowledge workers generally work under strict deadlines in fast-paced, stressful environments, and require organisational support.

Research purpose: The objective of this study was to examine empirically the effect of three leadership styles, namely transformational, transactional and laissez-faire, on job-relatedstress presenteeism in knowledge workers across a number of industries in South Africa.

Motivation for the study: Absenteeism has been the subject of much investigation but more research is required into the antecedents and consequences of presenteeism, the phenomenon of employees being physically present at work, but not fully functional and therefore unproductive. Illness as an antecedent to presenteeism has been studied, but limited attention has been given to presenteeism caused by stress. There are very few studies that investigate leadership styles as antecedents for JSRP and this study therefore sets out to provide quantitative evidence of this relationship.

Research design, approach and method: The researchers used a cross-sectional quantitative approach within the positivism research philosophy. Two questionnaires were administered: the multifactor leadership questionnaire form $6 \mathrm{~S}$ and the job-related-stress presenteeism questionnaire. Descriptive statistics and Pearson's product-moment correlation were used to answer the research questions. The participants $(N=242)$ were knowledge workers, representing 12 widely categorised industries. The researchers analysed job role descriptions to ensure the respondents were all knowledge workers.

Main findings: Transformational leadership has a higher negative correlation with JSRP than does transactional leadership, whereas laissez-faire leadership has no significant relationship with job stress or JSRP.

Practical/managerial implications: The research provides a compelling case for investment into transformational and transactional leadership development by showing the preventative effect that transformational leadership and, to a lesser degree, transactional leadership, has on stress-associated presenteeism.

Contribution/value-add: Presenteeism lowers organisational performance even more than absenteeism does, and exists at huge cost to employees' quality of work-life. This empirical study, the first to use valid, reliable questionnaires to investigate the relationship between transformational, transactional and laissez-faire leadership on the one hand, and JSRP on the other, suggests that transformational leadership development should be prioritised.

\section{Introduction}

Today's dynamic and rapidly changing business environment creates severe challenges for leaders (Cao \& Ramesh, 2008). Many organisations are having to operate with lean labour forces, and job demands place excessive pressure on employees (Hakanen, Schaufeli \& Ahola, 2008). Moreover, volatile market demands, leading to rising job uncertainty, are becoming a substantial stressor for employees (Pohling, Buruck, Jungbauer \& Leiter, 2016). It is therefore essential that organisations create and manage favourable work environments (Cummings et al., 2010); failure to do so negatively impacts long-term organisational performance (Schaufeli, Taris \& Van Rhenen, 2008). An important trait in creating a favourable working environment is leadership behaviour

Note: This article is partially based on the author's thesis of the degree of Doctor of Master of Business Administration at the Gordon Institute of Business Science, University of Pretoria, South Africa, received November 2013, available here: http://repository.up.ac.za/ bitstream/handle/2263/40595/George_Effect_2013.pdf 
as leaders motivate, engage and satisfy the needs of their employees (Bolden, Gosling, Marturano \& Dennison, 2003).

One of the challenges for today's leaders is presenteeism. Whitehouse (2005) defines this phenomenon as reduced productivity owing to events that distract employees from full productivity. Gosselin, Lemyre and Corneil (2013) contend that presenteeism is widespread, manifesting itself indiscriminately across occupational groups. This contention is taken into account in this study, which investigates the prevalence of presenteeism across a number of industries. Presenteeism is costly for organisations because of a lack of added value to the product or services rendered, or a decrement in employee performance (Hemp, 2004; MacGregor, Cunningham \& Caverley, 2008; Munro, 2007; Prochaska \& Prochaska, 2011). Organisations are therefore becoming increasingly concerned about the phenomenon as organisational performance is significantly impacted (PuigRibera, McKenna, Gilson \& Brown, 2008). A number of scholars, specifically Zopiatis and Constanti (2010), Mathieu, Neumann, Hare and Babiak (2014), Kara, Uysal, Sirgy and Lee (2013), conclude that leadership behaviour impacts followers' stress and burnout levels. The current research therefore included leadership as an important variable.

Globalisation has forced organisations to develop competitive advantage by employing competent, talented and dedicated employees. Called 'knowledge workers' by Drucker (1992) (as cited in Joo, 2010, p. 70), they '... apply theoretical and analytical knowledge that is acquired through formal education in developing new products or services'. Yet, one of the characteristics of knowledge workers is their high turnover rate, with the resulting high costs to the organisations that employ them (Scheepers \& Shuping, 2011).

Nielsen, Randall, Yarker and Brenner (2008) concluded that a relationship exists between a meaningful work environment, leadership and employee well-being. Effective leadership styles are therefore required to develop high-quality work environments that are conducive to knowledge workers' well-being and which ultimately contribute to achieving organisational goals. Knowledge workers are the focus of this study because of their importance to the success of organisations. Schaufeli et al. (2008) show that employee well-being is highly correlated with low levels of stress and leads to increased employee productivity. Other studies show that stress causes several negative outcomes, including burnout, employee turnover, as well as reduced productivity and well-being (Maslach \& Leiter, 2008; Tarafdar, Tu, RaguNathan \& Ragu-Nathan, 2007). These, in turn, lead to stressrelated presenteeism, an important construct under investigation in this study.

\section{Purpose}

There was therefore strong justification for conducting research in the field of presenteeism. This study set out to add to the body of knowledge about reducing presenteeism, particularly among knowledge workers, who play such an important role in achieving organisational competitive advantage. Its purpose was to empirically examine the effect of three leadership styles, namely transformational, transactional and laissez-faire leadership, on job-relatedstress presenteeism in knowledge workers across a number of industries in South Africa. Although leadership has been extensively researched, it remains difficult to understand the full extent of the complex interrelationships involved in leadership processes (Zopiatis \& Constanti, 2010). Leadership style is of particular interest to researchers (Ogbonna \& Harris, 2000) as it impacts both employee and organisational performance.

\section{Literature review}

As the main purpose of this study was to analyse the effect of leadership styles on employee job-stress-related presenteeism (JSRP), 'job-stress-related presenteeism' and 'leadership' are the constructs examined in this review.

\section{Presenteeism}

Until a few years ago, research focussed on absenteeism in relation to employee efficiency and organisational performance, while presenteeism was largely ignored (Gosselin et al., 2013). This trend has changed over the last 3-5 years, however, and the concept of presenteeism has gained credibility among academics and practitioners. Munro (2007) suggests that presenteeism is another aspect of absenteeism while Prater and Smith (2011) believe it is the antithesis of absenteeism. Aronsson and Gustafson (2005) state that work-related factors cause attendance pressure and define presenteeism as the phenomenon of people who, despite complaints and ill health that should prompt rest and absence from work, are still turning up at their jobs' (Aronsson, Gustafsson \& Dallner, 2000, p. 503). Gosselin et al. (2013) advise organisations to manage absenteeism without creating presenteeism.

The impact of absenteeism on the bottom line is well documented. For example, MacGregor et al. (2008) state that in Canada alone, billions of dollars are lost each year owing to absenteeism. Baker-McClearn, Greasley, Dale and Griffith (2010) report that absenteeism is the largest source of lost productivity for businesses in the United Kingdom. Absenteeism is trackable and it is possible to count its cost, but it is often impossible to tell when, and to what extent, employees are at work but simply not performing (presenteeism). MacGregor et al. (2008) report that the cost of sickness presenteeism may be even greater than that of sickness absenteeism. A white paper by the Health Enhancement Research Organisation (2014) suggests that presenteeism accounts for three-quarters of the cost of lost employee productivity, while absenteeism accounts for the fourth quarter. Demerouti, Le Blanc, Bakker, Schaufeli and Hox (2009) show that job demands placed on sick employees increase presenteeism and eventually lead to burnout. They say that "employees get trapped in a "loss spiral" as symptoms of burnout lead to an accumulation of job demands and less 
energy to cope with these demands' (p. 51). This is another example of presenteeism. Likewise, Chatterji and Tilley (2002) report that policies implemented by organisations to reduce absenteeism, such as reductions in sick pay, are more likely to increase presenteeism, which in turn, could lead to more illness and lower productivity. A US survey reported that $56 \%$ of employers experienced presenteeism because of some perceived problem in their organisation. Presenteeism in small organisations may be less when compared to medium and large organisations, as managers are more likely to regularly request feedback on tasks performed by subordinates (Matlay, 1999). Employee burnout and lost productivity were found to be 7.5 times greater in cases of presenteeism than absenteeism (Baker-McClearn et al., 2010), while McGregor, Iverson, Caputi, Magee and Ashbury (2014) report that the cost of presenteeism could be fourfold that of absenteeism.

Several studies focus on sickness as the antecedent for presenteeism (Aronsson, Gustafsson \& Dallner, 2000; BakerMcClearn et al., 2010; Demerouti et al., 2009), and allergies, rheumatoid arthritis and chronic back pain have been linked to it (Munro, 2007). While valuable, these studies are too narrow in approach for a full understanding of presenteeism (Gilbreath \& Karimi, 2012), rooted as they are solely in healthassociated matters.

\section{Job-stress-related presenteeism}

Gilbreath and Karimi (2012) assert that:

job-stress-related presenteeism is most closely the opposite of Rothbard's (2001, p. 656) conceptualisation of engagement, which focusses on attention - the cognitive availability and the amount of time one spends thinking about a role-and absorption - the intensity of one's focus on a role. (p. 116)

However, presenteeism is more than mere disengagement from, or low engagement in, work. Most definitions of engagement (Schaufeli, Salanova, Gonźalez-Roma \& Bakker, 2002) characterise it as pervasive and role-based, whereas presenteeism is considered to be more transitory and situational.

The current study focusses on presenteeism as it relates to job stress. JSRP is a construct developed by Gilbreath and Karamini (2012) as a factor, other than illness, that causes employees to be less focussed on tasks. Chae, Seo and Lee (2011) provide empirical evidence of links between job stress, organisational effectiveness and individual performance, and show that increased job stress results in weaker organisational performance.

While Karlin, Brondolo and Schwartz (2003) studied job stress in relation to support from supervisors, their study did not consider the leadership or supervisory styles that may have played an important role in moderating or mediating the relationship. This research, recognising that leadership style is inextricably interwoven into the creation of conducive working environments, sought to expand the work of
Gilbreath and Karimi (2012) on JSRP by providing an understanding of how it is impacted by leadership style.

\section{Leadership style}

The literature defines leadership in a number of ways, for example, as the ability to guide followers towards shared goals and as a form of influence (Madlock, 2008). Kouzes and Posner (1987) define leadership as an observable set of skills and abilities. Historically, leadership studies tended to focus on characteristics and personality traits, but the focus has shifted towards the perceptions of followers and the contextual nature of leadership (Robbins \& Coulter, 2005). New leadership theories pay greater attention to leaders' relationships with followers, as these contribute significantly to organisational success. Kara et al. (2013) quote a number of studies linking leadership styles to organisational commitment, organisational learning and adaptation, job satisfaction, employee motivation, as well as decreased absenteeism, a phenomenon particularly important to this study.

Bass's (1999) 'full range theory of leadership' suggests that there are three leadership styles, namely transformational, transactional and laissez-faire. According to Bodla and Nawaz (2010), transformational leaders are charismatic and motivate employees by inspiring them, considering them individually and stimulating their intellectual needs. Bass and Avolio (1993) suggest that transformational leadership is close to the prototype of leadership people have in mind when they describe their ideal leader, and that transformational leaders are more likely to be role models with whom subordinates want to identify. Transactional leaders, by contrast, specify tasks, monitor performance and provide a reward system. Laissez-faire leaders tend to avoid any involvement with their subordinates. Numerous researchers have investigated the relationship between these leadership behaviours and various phenomena, such as burnout, stress, job satisfaction and performance (Dale \& Fox, 2008; Danish \& Usman, 2010; Failla \& Stichler, 2008; Yang, Huang \& Wu, 2011; Zopiatis \& Constanti, 2010).

Hetland, Sandal and Johnsen (2007) studied the effects of leadership style on burnout in a Norwegian information technology firm and concluded that each style impacted the level of employee burnout differently. The study described burnout, which results from job stress, as a syndrome consisting of emotional exhaustion, depersonalisation and lack of professional accomplishment, and which has detrimental effects for both the individual employee and the organisation. The researchers concluded that high transformational leadership was linked to low levels of burnout whereas high transactional leadership, although also linked to low levels of burnout, had weaker associations than did transformational leadership. High passive-avoidant (laissez-faire) leadership was linked to high levels of burnout. A summary of the results from previous research on transformational leadership shows that it is positively correlated to job satisfaction (Nielsen, Yarker, Randall \& 
Munir, 2009; Wolfram \& Mohr, 2009), less stress (Bono \& Meredith, 2007; Munir, Nielsen \& Carneiro, 2010) and employee well-being (Skakon, Nielsen, Borg \& Guzman, 2010).

Transactional leadership theories are founded on the idea that leader-follower relations are based on a series of exchanges or implicit bargains between leaders and followers (Zopiatis \& Constanti, 2010). Research shows a relationship between transactional leadership styles and higher levels of stress in comparison with transformational leadership (Lyons \& Schneider, 2009). Other studies have found that transactional leadership is related to lower levels of burnout (Kanste, Kyngas \& Nikkila, 2007) and high job satisfaction as well as well-being (Morrison, Chappel \& Ellis, 1997), but that these relationships are weaker than those associated with transformational leadership. The Skakon et al. (2010) study shows similar results.

A laissez-faire leader is one who avoids decision-making or supervisory responsibility and believes in freedom of choice for employees, leaving them alone to do as they want (Goodnight, 2004). This leadership style implies failure on the part of the manager to take responsibility for managing. In some studies, laissez-faire leadership was found to be associated with increased psychological distress, a lack of social support and job strain (Nyberg et al., 2009). Early research by Sosik and Godschalk (2000), however, found no relationship between laissez-faire leadership on the one hand and stress and burnout on the other.

While the above studies provide insight into the effects of leadership style on job stress, they offer limited understanding of how leadership styles affect presenteeism, a particular dimension of job stress. If organisations understood the influence of these leadership styles on JSRP, they could maximise their employees' potential and performance, which in turn could lead to greater organisational performance.

\section{Research questions}

This study addresses the following research questions:

- Research question 1: What is the relationship between transformational leadership and JSRP?

- Research question 2: What is the relationship between transactional leadership and JSRP?

- Research question 3: What is the relationship between laissez-faire leadership and JSRP?

\section{Research design}

\section{Research approach}

The researchers used cross-sectional, descriptive and quantitative research to collect primary data to answer the research questions. This approach enabled them to understand whether employees suffered from JSRP and to ascertain employee perceptions of their managers' leadership styles. This study built on the work of Gilbreath and Karimi (2012) and therefore adopted a similar approach. Instead of investigating positive and negative behaviour, however, it sought to understand the effects of different leadership styles.

\section{Research participants}

The sample frame initially consisted of final-year Executive Masters in Business Administration (MBA) participants registered at a business school in Johannesburg, South Africa. The researchers deemed this frame appropriate as the focus of the study was on knowledge workers representing a variety of industries and at different levels within organisations. The researchers deemed the characteristics of the initial sample frame appropriate for these criteria. A dualsampling technique was used. Purposive sampling was employed for the initial request for participation, followed by snow-ball sampling when the initial participants forwarded the link to others (Saunders, Lewis \& Thornhill, 2012; Zikmund, Babin, Carr \& Griffin, 2009). These nonprobability sampling techniques led to a sample of $N=242$ knowledge workers in South Africa. Their job role descriptions provided information about their work context. They all had direct, face-to-face interaction with their managers. The dual-sampling technique ensured that the three different leadership styles described above were represented in the sample. The participants represented a variety of sectors. A total of $35.1 \%$ worked in the financial and insurance sector, $23.6 \%$ in the information technology sector and $17.8 \%$ in the energy sector. The remaining $23.5 \%$ worked in the general consulting services, education, engineering, FMCG, healthcare, law and public sectors.

\section{Measuring instruments}

\section{Leadership styles}

To understand participants' perceptions of their managers' leadership styles, the multifactor leadership questionnaire (MLQ form 6S) adapted from Vinger and Cilliers (2006) was used. The MLQ form 6S is a self-reporting scale consisting of 21 items and three sub-scales: transformational leadership style (12 items, e.g., 'I feel good to be around my manager'), transactional leadership style (six items, e.g., 'My manager helps me find meaning in my work') and laissez-faire leadership style (three items, e.g., 'My manager does not ask more of me than what is absolutely essential'). A five-point Likert scale was used to evaluate the leadership styles. The scale anchors were: 0 - not at all; 1 - once in a while; 2 sometimes; 3 - fairly often and 4 - frequently. The Cronbach's alpha for MLQ form 6S was $\alpha=0.86$, greater than the acceptable limit of 0.70 (Hair, Black, Babin, Anderson \& Tatham, 2006).

\section{Job stress and job-stress-related presenteeism}

To understand job stress, the researchers adapted the Gilbreath and Karimi (2012) JSRP scale. The researchers defined job stress in the questionnaire for participants as 'work-related activities caused by the demands placed on you by your leader', and it was measured using a two-item 
scale, for example, 'My job has been extremely stressful'. A four-point Likert scale was used to evaluate job stress, with the scale anchors being: 1 - strongly disagree; 2 - disagree; 3 - agree and 4 -strongly agree. The reliability and validity of the construct job stress were established by Gilbreath and Karimi (2012), and it is thus an adequate measure to understand job stress. The Cronbach's alpha for job stress was $\alpha=0.909$, greater than the acceptable limit of 0.70 (Hair et al., 2006).

To understand JSRP, the researchers again adapted Gilbreath and Karimi's (2012) scale. This construct was measured using a six-item scale, for example, 'Mental energy I'd otherwise devote to my work is wasted on work stressors'. A threepoint Likert scale was used to evaluate JSRP, with the following scale anchors: 1 - all the time; 2 - sometimes and 3 - never. The reliability and validity of the construct for JSRP were established by Gilbreath and Karimi (2012). The Cronbach's alpha for JSRP was $\alpha=0.828$, greater than the acceptable limit of 0.70 (Hair et al., 2006).

The reliability and validity of the instrument used to measure job stress were established by Gilbreath and Karimi (2012) and were acceptable. As the current study builds on their study, the instrument they used to measure job stress was employed in this research. Gilbreath and Karimi (2012) report a Cronbach's $\alpha=0.80$ for job stress.

Three open-ended questions were included in the questionnaire to understand what employees would like to change in their managers' leadership styles so that they could be more productive and not engage in presenteeism, for example, 'What changes in your manager would assist in alleviating stress and improve your performance?'

The instrument was pre-tested prior to the study, to ensure there were no problems in the design (Zikmund, 2003). It was administered to 20 randomly selected individuals, as well as an experienced researcher in the field of leadership, to ensure face and content validity. No significant changes were noted.

\section{Procedure and ethical considerations}

The questionnaire was distributed, via a link to an online survey, to 160 employees from different service-orientated industries, selected using purposive sampling. Snow-ball sampling was then used to gain more respondents as the initial participants were asked to forward the link to individuals within their networks. The exact response rate to the snow-balling sampling was difficult to ascertain; it did, however, allow for the collection of a greater number of respondents than were initially targeted, over the period from June to October 2013. A total of $N=272$ responses was received, of which $N=242$ responses were complete and retained for the final analysis. Ethical clearance was obtained from the University of Pretoria's Gordon Institute of Business Science Research Ethics Committee. All respondents were assured of confidentiality and anonymity, with participation being voluntary.

\section{Data analysis}

Several steps were taken to analyse the data gathered by this study using Statistical Package for Social Sciences (SPSS) version 22. The descriptive statistics (mean, median, mode and standard deviation), as well as skewness and kurtosis, were measured to indicate variation in the sample data collected, which allowed for a thorough study to be conducted on the topic, for example, percentage of males and females that took part in the survey; different respondent age groups; size of the organisation; and respondents' interactions with their managers.

Factor analysis using the principle component analysis (PCA) method was used to reduce the number of variables that need to be analysed, thus allowing for the grouping of variables to create a single value (Field, 2005). The KaiserMeyer-Olkin (KMO) index and the Bartlett's test of sphericity ensured that factor analysis was appropriate in this study as a data reduction tool. KMO indices greater than 0.5 and the Bartlett's test of sphericity significant at $p<0.05$ are suggested for an acceptable factor analysis (Field, 2005). Cronbach's alpha test was conducted to establish reliability of the research instrument in the South African setting. The generally agreed and accepted lower limit for Cronbach's alpha is 0.70 (Hair et al., 2006).

Each of the leadership styles was evaluated according to factors. Upon completion of the data-coding process, the numerical value for the questions under each factor was aggregated to create a score for that factor. Once the score for each factor was calculated, the final score for the perceived leadership style was the average of the factors, relevant to the leadership style. The same process was followed for all the variables so that each variable had a final score based on the participant's response.

Final scores for each of the variables needed to be calculated to evaluate whether a relationship existed between leadership style and JSRP. For example: if a respondent selected option ' 3 ' for all the questions in the questionnaire, each factor in the leadership section of the questionnaire had three questions, jobs stress had two and JSRP had six. The score for each factor was aggregated to give a score of 9 ( 3 for leadership selecting option 3 for all three questions, +3 for job stress selecting option 3 across both questions, +3 for JSRP selecting 3 for all six questions) $=9$ :

- Factor 1 (idealised influence): score 9.

- Factor 2 (inspirational motivation): score 9.

- Factor 3 (intellectual stimulation): score 9.

- Factor 4 (individualised consideration): score 9.

- Factor 5 (contingent reward): score 9.

- Factor 6 (management by exception): score 9 .

- Factor 7 (laissez-faire): score 9.

Factors 1-4 are related to transformational leadership and hence the final score for transformational leadership would be the average of Factors 1-4 (Factor $1+$ Factor $2+$ Factor $3+$ Factor 4$) / 4=(9+9+9+9) / 4=36 / 4=9$. Thus, the 
respondent's score for transformational leadership would be 9 . Similarly, Factors 5 and 6 are related to transactional leadership, hence the final score for transactional leadership would be the average of Factors 5 and 6 (Factor $5+$ Factor $6) / 2=(9+9) / 2=9$. Factor 7 is related to laissez-faire leadership, hence the final score would be the average of Factor 7 (Factor 7 ) $/ 1=9 / 1=9$. The final score for job stress would be the average between the two questions measuring job stress, and if a participant scored 3 for each of the questions, the final score would be $(3+3) / 2=3$. Similarly, JSRP has six questions, and if a participant scored 3 for each question, the final score would be the average of the scores for each question $(3+3+3+3+3+3) / 6=3$.

The same process was followed for all respondents and the overall average was calculated for each of the factors. If the overall average calculated was 2.5 for all the variables, then a score $\leq 2.5$ would be categorised as 'low' and a $>2.5$ would be categorised as high. From the example, the respondent's score was categorised as high for all the variables to test for associations between them.

Once the final scores for each respondent for each of the variables were calculated, descriptive statistics were used to categorise the data. The mean for the final score of the three variables was calculated by adding the values of the scores and then dividing them by the number of observations. Based on the mean, each respondent's score on the three constructs was then categorised as 'high' or 'low'. The low and high categories for each variable were compared against each other.

To understand if there were differences between the high and low categories, the one-sample $t$-test was employed. The test also ensured that the sample was representative of the population (Field, 2005). The test was applied to each factor to determine if the responses were significantly different, rather than based only on percentage splits. Once the researchers were confident that the difference between the high and low categories was significant, they subjected the data to correlational analysis. To answer the research questions, Pearson's correlation tests, chi-square and cross-tabulations were used to establish if there were any associations between factors. The chi-square test is used to find relationships between two variables, while cross-tabulation shows the frequency of joint occurrences between the two variables. For cross-tabulations, two categorical variables were used. The variables were categorised as 'low' or 'high' based on their final score, as described above. The observed counts and percentages in a cross-tabulation describe the relationship. A $2 \times 2$ cross-tabulation was performed between two variables and the same two-step process was followed to understand the associations between all the variables. All statistical analyses were performed at a 95\% confidence interval, $p=0.05$.

\section{Results}

A total of 272 responses were received, of which 242 were complete. The sample consisted of 108 female and 134 male respondents. A total of 44 respondents were in the age group of 20-29 years, 124 were aged between 30 and 39 years, 62 were aged between 40 and 49 years and 12 were aged 50 years and above. The sample comprised 12 sectors of the economy, with the largest responses from the finance and insurance (35.1\%), information technology (23.6\%) and energy (17.8\%) sectors. The remaining respondents $(23.5 \%)$ worked in consulting services, education, engineering, FMCG, healthcare, law, the public sector and 'others'. A total of 221 respondents were employed in organisations with more than 50 employees and 21 in organisations with less than 50 employees. A total of 138 respondents met with their managers more than once a week, 67 once a week and 37 very rarely.

Table 1 indicates that PCA was appropriate, based on the KMO measures and Bartlett's test of sphericity.

While the Cronbach's alpha results for laissez-faire leadership were weak, the researchers retained the factor, as this may not show uni-dimensionality of the construct, see Table 2. All other measures of reliability were acceptable (Hair et al., 2006).

A total of seven sub-factors were analysed within the three leadership styles. Transformational leadership: four sub-factors (idealised influence, inspirational motivation, intellectual stimulation and individualised consideration); transactional leadership: two sub-factors (contingent reward and management by exception) and laissez-faire: one subfactor (no formal structure). Table 3 reports on the mean and standard deviation of the leadership sub-scales from the responses.

There is a good spread of data based on the options selected by the respondents that provide great value in understanding the relationship between leadership styles and JSRP.

The summary of the sub-constructs is displayed in Table 4 .

\section{Leadership styles}

The $t$-test indicated that, with regard to the sub-scales.

TABLE 1: Results of principle component analysis, Kaiser-Meyer-Olkin index, Bartlett's test of sphericity, Cronbach's alpha and average score for factors.

\begin{tabular}{lcccc}
\hline Dimension & KMO & \multicolumn{3}{c}{ Bartlett's test of sphericity } \\
\cline { 2 - 5 } & & Chi-square & $\begin{array}{c}\text { Degrees of } \\
\text { freedom }\end{array}$ & Significance \\
\hline Transformational & 0.952 & 2210.567 & 66 & 0.000 \\
Transactional & 0.785 & 495.939 & 15 & 0.000 \\
Laissez-faire & 0.568 & 61.441 & 3 & 0.000 \\
Job stress & 0.500 & 284.803 & 1 & 0.000 \\
JSRP & 0.841 & 502.725 & 15 & 0.000 \\
\hline
\end{tabular}

JSRP, job-stress-related presenteeism; KMO, Kaiser-Meyer-Olkin.

TABLE 2: Cronbach's alpha coefficients.

\begin{tabular}{lcc}
\hline Dimension & Cronbach's alpha & Number of items \\
\hline Transformational & 0.936 & Q1-12 \\
Transactional & 0.696 & Q13-18 \\
Laissez-faire & 0.532 & Q19-21 \\
Job stress & 0.909 & Q22-23 \\
$\begin{array}{l}\text { Job-stress-related } \\
\text { presenteeism }\end{array}$ & 0.828 & Q24-29 \\
\hline
\end{tabular}


TABLE 3: Descriptive statistics of the leadership style sub-factors.

\begin{tabular}{|c|c|c|c|c|c|c|}
\hline Questions & Mean & Median & Mode & Std. deviation & Skewness & Kurtosis \\
\hline Question 1 & 2.64 & 3 & 3 & 1.08 & -0.43 & -0.63 \\
\hline Question 2 & 2.46 & 3 & 3 & 1.30 & -0.56 & -0.70 \\
\hline Question 3 & 2.54 & 3 & 3 & 1.27 & -0.59 & -0.68 \\
\hline Question 4 & 2.31 & 2 & 3 & 1.21 & -0.25 & -0.87 \\
\hline Question 5 & 1.84 & 2 & 1 & 1.22 & 0.12 & -0.96 \\
\hline Question 6 & 1.83 & 2 & 2 & 1.34 & 0.09 & -1.12 \\
\hline Question 8 & 1.98 & 2 & 1 & 1.25 & 0.01 & -1.02 \\
\hline Question 9 & 1.87 & 2 & 2 & 1.20 & 0.03 & -0.97 \\
\hline Question 10 & 1.90 & 2 & 1 & 1.36 & 0.15 & -1.15 \\
\hline Question 11 & 1.95 & 2 & 1 & 1.24 & 0.05 & -1.08 \\
\hline Question 12 & 1.59 & 1 & 0 & 1.35 & 0.38 & -1.08 \\
\hline Question 13 & 1.48 & 1 & 0 & 1.34 & 0.46 & -0.97 \\
\hline Question 14 & 1.67 & 2 & 1 & 1.30 & 0.31 & -0.98 \\
\hline Question 16 & 2.95 & 3 & 4 & 1.06 & -0.90 & 0.23 \\
\hline Question 17 & 2.63 & 3 & 3 & 1.18 & -0.63 & -0.45 \\
\hline Question 18 & 1.90 & 2 & 3 & 1.26 & 0.03 & -1.04 \\
\hline Question 19 & 2.58 & 3 & 3 & 1.12 & -0.77 & 0.14 \\
\hline Question 20 & 2.34 & 3 & 3 & 1.19 & -0.44 & -0.66 \\
\hline Question 21 & 1.69 & 2 & 2 & 1.25 & 0.11 & -1.10 \\
\hline
\end{tabular}

TABLE 4: Sub-construct means, standard deviations and $t$-values.

\begin{tabular}{lccc}
\hline Leadership style & Mean & Std. deviation & $t$ \\
\hline Transformational leadership & 6.25 & 3.028 & - \\
Idealised influence & 7.64 & 3.309 & $2.03^{*}$ \\
Inspirational motivation & 5.98 & 3.167 & $1.46^{* *}$ \\
Intellectual stimulation & 5.93 & 3.332 & $1.67^{* *}$ \\
Individualised consideration & 5.43 & 3.419 & $2.86^{*}$ \\
Transactional leadership & 6.08 & 2.600 & - \\
Contingent reward & 4.68 & 3.435 & $2.95^{*}$ \\
Management by exception & 7.48 & 2.419 & $3.37^{*}$ \\
Laissez-faire leadership & 6.61 & 2.560 & $1.32^{* *}$ \\
\hline
\end{tabular}

$*, p<0.05 ; * *, p>0.05$

\section{Idealised influence}

Respondents reported that they had faith and trust in their managers and perceived them as role models. There was a significant difference between respondents that reported they had faith and trust in their managers and perceived them as role models and those that did not. The differences in responses were therefore not owing to chance but owing to real differences that could be expected in the population as well.

\section{Inspirational motivation}

Respondents reported that their managers do not provide a vision for their employees to find meaning in their work. There were no significant differences between respondents who reported that their managers provide a vision for their employees to find meaning in their work, and those who did not. This indicates that the differences observed in response to inspirational motivation were not 'real' but owing to chance.

\section{Intellectual stimulation}

Managers do not provide intellectual stimulation for their employees to find meaning in their work. There was no significant difference between those respondents who reported that their managers provide intellectual stimulation to find meaning in their work, and those who did not. This indicates that the differences observed in response to intellectual stimulation were not 'real' but owing to chance.

\section{Individualised consideration}

Managers show little interest in their well-being. There was a significant difference between respondents who reported that their managers show little interest in their well-being and those who did not. These differences were therefore not owing to chance but reflected real differences that can be expected in the population as well.

\section{Contingent reward}

There was a significant difference between respondents who reported that their managers emphasise what is expected from them and recognise their accomplishments, and those who did not. The difference is real and not owing to chance and can be expected in the population as well.

\section{Management by exception}

There was also a significant difference between the respondents who reported that their managers inform them about their job requirements and are content with standard performance, and those who did not. These differences are therefore not owing to chance.

\section{No formal structure}

There was no significant difference between respondents reporting that their managers are content with subordinates doing their own thing, and those who reported they were not. Therefore, what was observed is not 'real' and not applicable to the population. 
Leadership style was considered as a factor contributing to job stress, which in turn caused JSRP. There was a positive moderate correlation between job stress and JSRP, $r(240)=$ $0.529, p<0.05$.

Once job stress and JSRP were categorised as low or high, a cross-tabulation was conducted to evaluate if low job stress is related to low JSRP, and vice versa. All expected cell frequencies were greater than five, and there was a significant association between high and low job stress and high and low JSRP, $X^{2}(1)=37.614, p=0.000$.

Gilbreath and Karimi (2012) established that job stress caused by positive or negative supervisor behaviour results in JSRP. In this study, leadership style was considered to be the main factor that causes job stress, which in turn causes JSRP. For both the job stress and JSRP sections in the questionnaire, the final scores were calculated using the process defined above. Pearson's $r$ correlation test was conducted to assess significant associations between the variables of leadership, job stress and JSRP. Cross-tabulation and chi-square tests were also performed to establish if a significant relationship existed between these two variables.

As Table 5 indicates, there is a moderate positive association between job stress and JSRP, indicating that an increase in job stress increases JSRP. Transformational leadership and transactional leadership are significantly associated with JSRP, while laissez-faire leadership is not significantly associated with JSRP, at a $95 \%$ confidence interval. For transformational leadership, results indicate a weak negative

TABLE 5: Pearson's correlation and associated chi-square values between leadership styles and job stress and job-stress-related presenteeism.

\begin{tabular}{lll}
\hline Dimension & Pearson's correlation & Chi-square \\
\hline Transformational leadership and JSRP & $-0.271^{* *}$ & $8.939 * *$ \\
Transactional leadership and JSRP & $-0.196^{* *}$ & $6.537^{* *}$ \\
Laissez-faire leadership and job stress & 0.106 & 0.130 \\
Laissez-faire leadership and JSRP & 0.121 & 0.110 \\
Job stress and JSRP & $0.529 * *$ & $37.614^{* *}$ \\
\hline
\end{tabular}

JSRP, job-stress-related presenteeism.

$* *, p<0.05$

TABLE 6: Cross-tabulation table.

\begin{tabular}{|c|c|c|c|c|}
\hline \multirow[t]{2}{*}{ Dimensions } & \multicolumn{2}{|c|}{$\begin{array}{l}\text { Job-stress-related } \\
\text { presenteeism }\end{array}$} & \multicolumn{2}{|c|}{ Job stress } \\
\hline & High & Low & High & Low \\
\hline \multicolumn{5}{|c|}{ Transformational leadership } \\
\hline High & 54.0 & 60.0 & - & - \\
\hline$\%$ within transform & 47.4 & 52.6 & - & - \\
\hline Low & 85.0 & 43.0 & - & - \\
\hline$\%$ within transform & 66.4 & 33.6 & - & - \\
\hline \multicolumn{5}{|c|}{ Transactional leadership } \\
\hline High & 50.0 & 54.0 & - & - \\
\hline$\%$ within transact & 48.1 & 51.9 & - & - \\
\hline Low & 89.0 & 49.0 & - & - \\
\hline$\%$ within transact & 64.5 & 35.5 & - & - \\
\hline \multicolumn{5}{|c|}{ Laissez-faire leadership } \\
\hline High & 78.0 & 60.0 & 83.0 & 55.0 \\
\hline$\%$ within Laissez & 56.5 & 43.5 & 60.1 & 39.9 \\
\hline Low & 61.0 & 43.0 & 65.0 & 39.0 \\
\hline$\%$ within Laissez & 58.7 & 41.3 & 62.5 & 37.5 \\
\hline
\end{tabular}

correlation; JSRP decreases as 'level' of transformational leadership increases. For transactional leadership, there is a weak positive relationship; JSRP increases with an increase in the 'level' of transactional leadership.

Table 5 also shows the chi-square results. There is a significant positive relationship between job stress and JSRP. It is therefore possible to evaluate the relationship between the leadership styles under study and JSRP, as both tests demonstrate a strong association between job stress and JSRP.

Cross-tabulation tests (Table 6) were also performed to establish if there was a significant relationship between the two variables.

\section{Results for research question 1 (What is the relationship between transformational leadership and job-stress-related presenteeism?)}

There is a negative relationship between transformational leadership and JSRP. The cross-tabulation below indicates that $60(52.6 \%)$ of the respondents who perceived their managers as having high transformational leadership style exhibited low JSRP and $85(66.4 \%)$ respondents, whose managers had low transformational leadership style, exhibited high JSRP. In both instances (low and high categories), the results point towards an association between transformational leadership style and JSRP; there is a strong positive association between low transformational leadership style and high JSRP. The Pearson's $r$ statistic for correlation between transformational leadership and JSRP is -0.271 . The correlation value is close to 0 , indicating that there is a relationship between the two variables, although it is weak. However, it is still significant and thus important. As transformational leadership style value increases, the JSRP value decreases.

\section{Results for research question 2 (What is the relationship between transactional leadership and job-stress-related presenteeism?)}

There is a negative relationship between transactional leadership and JSRP. The results from the cross-tabulation indicate that $54(51.9 \%)$ of the respondents who perceived their managers as having high transactional leadership styles exhibited low JSRP. In both instances (low and high categories), the results point towards an association between transactional leadership style and JSRP. The chi-square test results indicate that there is a strong relationship between the two variables, statistically significant at significance level $0.05(p<0.05)$.

The Pearson's correlation shows that the correlation is statically significant at $1 \%$ significance level as the significance value is 0.002 . The Pearson's $r$ statistic for correlation between job stress and JSRP is -0.196 . The correlation value shows a weak relationship (close to 0) between the two variables. However, it is still significant and thus important: the change in one variable is correlated with changes in the other variable, in this case transactional leadership style and JSRP. 
The relationship is negative, which means as transactional leadership style increases, JSRP decreases. Both these tests demonstrate an association between the two variables (transactional leadership style and JSRP), but this association is weaker than that between transformation leadership style and JSRP. The transactional leadership style is negatively correlated with JSRP, while transformational leadership style results in lower JSRP.

\section{Results for research question 3 (What is the relationship between laissez-faire leadership and job-stress-related presenteeism?)}

There is no relationship between laissez-faire leadership and JSRP. The cross-tabulation results indicate that both high and low laissez-faire leadership styles cause high job stress. There is therefore no relationship between these two variables. The chi-square test result also indicates the lack of a relationship between the two variables as they are statistically insignificant, even at $p<0.05$. In addition, the Pearson's correlation shows no correlation between the two variables.

Figure 1 depicts the findings of the study. Overall, a multiple regression was computed to predict job stress from JSRP, transformational leadership, transactional leadership and laissez-faire leadership styles. There was linearity as assessed through partial regression plots and plots against the studentised residuals against predicated values. The DurbinWatson was 2118, therefore independent of residuals. No evidence of multicollinearity was noted as tolerance values were less than 0.1 . The multiple regression statistically predicted job stress, $F(4237)=3886, p<0.05$, adjusted $R^{2}=0.046$. Only JSRP added statistically to the prediction, $p<0.05$. Regression coefficients and standard errors are presented in Table 7.

\section{Discussion Outline of the results}

Presenteeism is a growing concern for organisations (Hemp, 2004; MacGregor et al., 2008; Prochaska \& Prochaska, 2011). Managing stress has become an acutely important skill for leaders today, as increasing job demands burden knowledge workers even further. If not properly managed, knowledge workers could withhold their intellectual capital and take it with them, if and when they choose to leave (Pearce, 2007). Studies have also revealed the negative impact job stress has on productivity and organisational effectiveness (Cummings et al., 2010). The objective of this study was to build on Gilbreath and Karimi's (2012) research; to understand the impact and influence of leadership style on presenteeism,

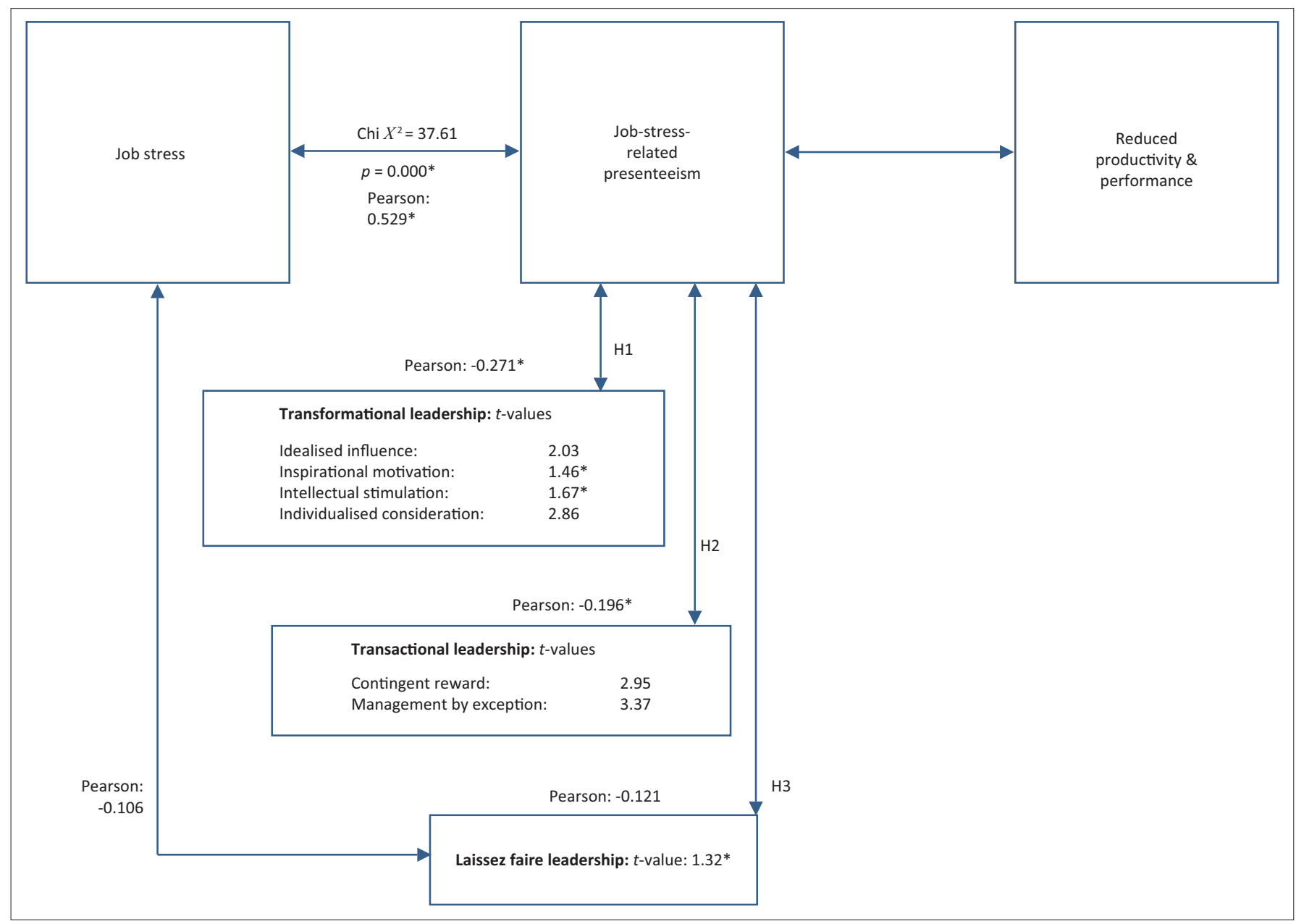

*, significant at $p<0.05$

FIGURE 1: Illustration of Pearson correlation coefficients, $t$-values and chi-square of stress, job-stress-related-presenteeism and leadership style. 
TABLE 7: Summary of multiple regression analysis.

\begin{tabular}{lccc}
\hline Variable & $\boldsymbol{B}$ & SE $\boldsymbol{B}$ & $\boldsymbol{t}$ \\
\hline Constant & 5.243 & 0.607 & $8.643^{*}$ \\
JSRP & -0.551 & 0.160 & $-3.443^{*}$ \\
$\begin{array}{l}\text { Transformational } \\
\text { leadership }\end{array}$ & -0.042 & 0.077 & 0.585 \\
$\begin{array}{l}\text { Transactional } \\
\text { leadership }\end{array}$ & -0.046 & 0.092 & 0.615 \\
$\begin{array}{l}\text { Laissez-faire } \\
\text { leadership }\end{array}$ & -0.008 & -0.100 & 0.881 \\
$\begin{array}{l}B, \text { unstandardised regression co-efficient; SE B, Standard error of the co-efficient; JSRP, job- } \\
\text { stress-related presenteeism. } \\
*, p<0.05\end{array}$ & & \\
& &
\end{tabular}

thus adding to the body of knowledge on the topic and helping organisations to deal with presenteeism more effectively. In Gilbreath and Karimi's (2012) study on JSRP, the sample was drawn from Australian hospital employees. The current study took a more holistic approach by focussing on several industries, in the belief that presenteeism is likely to be found in all sectors.

This study aimed to provide a thorough analysis of presenteeism, based on leadership styles, across all types of organisations and industries. Interactions with managers were measured to ensure that the three leadership styles were covered. The data on interaction was well scattered, from 'more than once a week' to 'rarely meeting with managers'. The demographics of the sample population meant that the data gathered for the study were appropriate to answer the research questions.

\section{Job stress and job-stress-related presenteeism}

Several researchers (Phillips, Sen \& McNamee, 2007; Schaufeli et al., 2008; Skakon et al., 2010) have shown that knowledge workers are subjected to work-related stress on a daily basis owing to leadership behaviour, workload, work-life balance and performance, as well as job security pressures. According to the Gilbreath and Karimi (2012) study, job stress results in JSRP. To analyse the impact of leadership style on JSRP, the association between job stress and JSRP needed to be validated, and the researchers discovered a strong association.

The cross-tabulation also indicates that a high percentage of respondents who experience job stress engage in presenteeism. This suggests that as knowledge worker stress reduces, presenteeism will also be reduced. The results show that job stress causes presenteeism. The results of the tests successfully validated Gilbreath and Karimi's (2012) claim that presenteeism is a much broader concept than previously thought, with numerous possible causes. The results also verified the utility and validity of their tool and may prove very useful for further research on understanding the effects of job stress on employees. The results may benefit organisations considerably as they allow them to focus on factors other than sickness to reduce presenteeism.

\section{Transformational leadership style and job-stress-related presenteeism}

Research on leadership style and job stress by Munir et al. (2010) showed that transformational leaders cause less job stress among subordinates. As job stress is significantly associated with presenteeism, measurements of the impact of transformational leadership style on presenteeism are discussed here. The results indicate that $66.4 \%$ of the respondents who rated their managers as exhibiting low transformational leadership style engage in high levels of presenteeism. This is a significant result and indicates that transformational leadership style is effective in reducing presenteeism.

The average score for idealised influence was noticeably higher than that for the remaining three factors associated with transformational leadership. Bass (1999) states that a leader is most likely to be strong on some factors but not all, which was confirmed by the results of this study. However, the results should encourage transformational leaders to develop themselves on all factors. The higher the score for each factor, the better the overall average score for the leader, which may result in reduced presenteeism. Associations between the individual factors and presenteeism were not tested, as the variable evaluated was leadership style (derived from the average score of the four factors). The result provides motivation for further research to understand the impact of each factor on presenteeism.

Although numerous studies (Bono \& Meredith, 2007; Munir et al., 2010) have been conducted on the relationship between transformational leadership style and organisational outcomes, the current study is the first to investigate the impact of leadership styles on JSRP. The results suggest that leaders who adopt transformational leadership styles reduce employee presenteeism. Organisations may therefore benefit by developing transformational leaders, who are already known to significantly increase organisational effectiveness (Nielsen et al., 2008; Zopiatis \& Constanti, 2010).

\section{Transactional leadership style and job-stress-related presenteeism}

Studies by Lyons and Schneider (2009) show that transactional leaders cause job stress, as their relationship is based on a series of exchanges or implicit bargains between them and their followers (Zopiatis \& Constanti, 2010). The current study found that $64.5 \%$ of respondents who rated their managers as exhibiting low transactional leadership style engage in high levels of presenteeism.

The average score for 'management by exception' was considerably higher than that for 'contingent reward'. This means that respondents feel they are not being rewarded for good work, which could be a reason for subordinates to engage in presenteeism. Rewards and recognition are important as they motivate subordinates to perform better (Danish \& Usman, 2010). The higher the score for each factor, the better the overall average score for the leader, which may result in reduced presenteeism. This is the first study to measure transactional leadership style in conjunction with JSRP. The systematic review by Skakon et al. (2010) on leadership and employee well-being shows that transactional leadership style has positive associations with employee 
well-being and negative associations with job stress. The results from this study indicate that transactional leadership style is negatively correlated to JSRP. They complement previous studies and suggest that leaders who adopt transactional leadership style reduce employee presenteeism. However, the association is weaker than that found between transformational leadership and reduced presenteeism, a result similar to those of previous studies on other employee outcomes (Skakon et al., 2010). Leaders that adopt transactional leadership styles can reduce presenteeism but there is incentive to develop the characteristics of transformational leadership style as it has more influence on presenteeism. The combination of both leadership styles may allow organisations to reduce presenteeism significantly.

\section{Laissez-faire leadership style and job-stress-related presenteeism}

Skakon et al. (2010), in their systematic review of leadership styles of the last three decades, report that Skogstad, Einarsen, Torsheim, Assland and Hetland (2007) found laissez-faire leadership style and job stress to be related. However, Skogstad et al. (2007) also reported that Sosik and Godschalk (2000) found no relationship between them. The Cronbach's alpha score for the current study did not meet the benchmark score of 0.70 . The internal validity of the data for this leadership style is therefore questionable and it might be necessary to revalidate the questions on the MLQ form $6 S$ instrument used to measure laissez-faire leadership style. It could be a reason why previous research has not shown conclusive results. The results of this study are similar to the results of the Sosik and Godschalk's (2000) study on laissezfaire leadership style and job stress.

This study found no statistically significant relationship between laissez-faire leadership style and JSRP. Some researchers (Lyons \& Schneider, 2009) mention that laissez-faire leadership style is not actual leadership, which may be true.

\section{Managerial implications}

Results show the significant influence of transformational leadership style on JSRP. There is evidence to suggest that transformational leaders are more likely to find less presenteeism among their subordinates. Furthermore, the results provide evidence that transactional leadership style is also negatively associated with JSRP but that these associations are weaker than those between transformational leadership styles and JSRP. This is consistent with the theories (Lyons \& Schneider, 2009; Munir et al., 2010) mentioned earlier about leadership style and job stress. The test results for laissez-faire leadership style and job stress show that there is no relationship between these variables, and similarly between laissez-faire leadership style and JSRP. As there has been only one reported study (Gilbreath \& Karimi, 2012) to measure JSRP, the results of this study add to this body of knowledge. The results confirm that leadership style can be used as a predictor of JSRP and that certain leadership styles may affect the degree to which employees experience JSRP.

\section{Limitations of the study and directions for future research}

Previous research has focussed mainly on 'sickness presenteeism' (Demerouti et al., 2009; Hansen \& Andersen, 2008; Johns, 2010). It is hoped that the new conceptualisation of presenteeism presented in this study will encourage further research in this field. The objective was to evaluate the effect of leadership style on stress-related presenteeism using the 'full range theory of leadership' (Bass, 1999; Bass \& Avolio, 2004); future studies into the impact on stressrelated presenteeism of other kinds of leadership, such as authentic, situational or servant leadership styles, would be beneficial.

One limitation of this study is the lack of industry-specific analysis on stress presenteeism. Valuable information could be drawn from the nature, size and type of industry. It will also be important for future studies to focus on the relationship between gender and stress-related presenteeism. Prater and Smith (2011) show that presenteeism is the antithesis of absenteeism. In future research, it will be important to evaluate if the factors that cause absenteeism also contribute to presenteeism.

The study confirmed the relation between job stress and presenteeism, supporting Gilbreath and Karimi's (2012) view that presenteeism can have numerous possible causes. It will be important for future research to consider presenteeism as an outcome with a variety of antecedents, and to discover which antecedents are most prevalent and have the strongest effects.

\section{Conclusion}

In conclusion, presenteeism has become an important subject of investigation as it has been shown to be even more costly than absenteeism. This study sought to advance the research into this phenomenon by analysing the effect of three leadership styles on employee JSRP. Specifically, it attempted to expand the research of Gilbreath and Karimi (2012) by providing an understanding of how JSRP is impacted by leadership style. This was felt to be vital, as if organisations understood the influence of leadership on JSRP they could maximise their employees' potential and performance, which in turn could lead to greater organisational performance.

The results provide a compelling case for investment into transformational and, to a lesser extent, transactional leadership development. They show the preventative effect that both styles of leadership have on stress-associated presenteeism. Laissezfaire leadership, on the contrary, was shown to have no significant relationship with job stress or JSRP.

The study suggests that leaders who adopt transformational leadership styles are most successful in reducing employee presenteeism and therefore that this type of leadership development should be prioritised. 
Leaders that adopt transactional leadership styles can also reduce presenteeism, but there is incentive to develop the characteristics of transformational leadership style as it has more influence on presenteeism. The combination of both leadership styles, however, may allow organisations to reduce presenteeism significantly.

It is hoped that these findings will prompt organisations to focus their efforts on developing leaders capable of reducing presenteeism which in turn will increase their competitive advantage.

\section{Acknowledgements Competing interests}

The authors declare that they have no financial or personal relationships that may have inappropriately influenced them in writing this article.

\section{Authors' contributions}

R.G. was the primary researcher, who collated the data. M.C. was the research study supervisor of R.G. C.B.S. made conceptual contribution at the design phase, assisted in literature review and in compiling the article on research.

\section{References}

Aronsson, G., \& Gustafsson, K. (2005). Sickness presenteeism: Prevalence, attendancepressure factors and an outline of a model for research. Journal of Occupationa and Environmental Medicine, 47(9), 958-966. https://doi.org/10.1097/01. jom.0000177219.75677.17

Aronsson, G., Gustafsson, K., \& Dallner, M. (2000). Sick but yet at work. An empirical study of sickness presenteeism. Journal of Epidemiology and Community Health, 54(7), 502-509. https://doi.org/10.1136/jech.54.7.502

Baker-McClearn, D., Greasley, K., Dale, J., \& Griffith, F. (2010). Absence management and presenteeism: The pressures on employees to attend work and the impact of attendance on performance. Human Resource Management Journal, 20(3), of attendance on performance. Human Resource Managem

Bass, B.M. (1999). Two decades of research and development in transformational leadership. European Journal of Work and Organisational Psychology, 8(1), 9-32. https://doi.org/10.1080/135943299398410

Bass, B.M., \& Avolio, B.J. (1993). Transformational leadership and organisational culture. Public Administration Quarterly, 17(1), 112-121.

Bass, B.M., \& Avolio, B.J. (2004). Multifactor leadership questionnaire: Manual and sampler set. (3rd edn.). Palo Alto, CA: Mind Garden.

Bodla, M.A., \& Nawaz, M.M. (2010). Comparative study of full range leadership model among faculty members in public and private sector higher education institutes and universities. International Journal of Business and Management, 5(4), 208-214.

Bolden R., Gosling, J., Marturano, A., \& Dennison, P. (2003). A review of leadership theory and competency frameworks: Edited version of a report for chase
consulting and the management standards centre. Centre for Leadership Studies. consulting and the management stand
Exeter: University Exeter, pp. 1-44.

Bono, J.E., \& Meredith, A. (2007). Personality and emotional performance: Extraversion, neuroticism, and self-monitoring. Journal of Occupational Health Psychology, 12(2), 177-192. https://doi.org/10.1037/1076-8998.12.2.177

Cao, L., \& Ramesh, B. (2008). Agile requirements engineering practices: An empirical study. IEEE Software, 25(1), 60-67. https://doi.org/10.1109/MS.2008.1

Chae, S.W., Seo, Y.W., \& Lee, K.C. (2011). An empirical analysis of the effects of IT professionals' emotional dissonance on creativity revelation processes and individual creativity. In U- and E-service, science and technology (Vol. 264, pp. 168-176). Berlin: Springer.

Chatterji, M., \& Tilley, C.J. (2002). Sickness, absenteeism, presenteeism, and sick pay. Oxford Economic Papers, 54(4), 669-687. https://doi.org/10.1093/oep/54.4.669

Cummings, G.G., MacGregor, T., Davey, M., Lee, H., Wong, C.A., Lo, E., et al. (2010). Leadership styles and outcome patterns for the nursing workforce and work environment: A systematic review. International Journal of Nursing Studies, 47(3) 363-385. https://doi.org/10.1016/j.ijnurstu.2009.08.006

Dale, K., \& Fox, M.L. (2008). Leadership style and organisational commitment: Mediating effect of role stress. Journal of Managerial Issues, 20(1), 109-130.
Danish, R.Q., \& Usman, A. (2010). Impact of reward and recognition on job satisfaction and motivation: An empirical study from Pakistan International Journal of and motivation: An empirical study from Pakistan. International Journal of
Business Management, 5(2), 159-167. https://doi.org/10.5539/ijbm.v5n2p159

Demerouti, E., Le Blanc, P.M., Bakker, A.B., Schaufeli, W.B., \& Hox, J. (2009). Present but sick: A three-wave study on job demands, presenteeism and burnout. Career Development International, 14(1), 50-68. https://doi.org/10.1108/ 13620430910933574

Failla, K.R., \& Stichler, J.F. (2008). Manager and staff perceptions of the manager's leadership style. Journal of Nursing Administration, 38(11), 480-487. https://doi. org/10.1097/01.NNA.0000339472.19725.31

Field, A. (2005). Discovering statistics using SPSS. London: SAGE.

Gilbreath, B., \& Karimi, L. (2012). Supervisor behavior and employee presenteeism. International Journal of Leadership Studies, 7(1), 114-131.

Goodnight, R. (2004). Laissez-faire leadership. In G.R. Sorenson, G. Jones, J.M. Burns, (Eds.), Encyclopedia of leadership (pp. 820-824). Thousand Oaks, CA: Sage.

Gosselin, E., Lemyre, L., \& Corneil, W. (2013). Presenteeism and absenteeism Differentiated understanding of related phenomena. Journal of Occupational Differentiated understanding of related phenomena. Journal of 0 Health Psychology, 18(1), 75-86. https://doi.org/10.1037/a0030932
Her

Hair, J.F., Black, B., Babin, B., Anderson, R.E., \& Tatham, R.L. (2006). Multivariate data analysis. (6th edn.). Upper Saddle River, NJ: Prentice Hall.

Hakanen, J.J., Schaufeli, W.B., \& Ahola, K. (2008). The job demands-resources model: A three-year cross-lagged study of burnout, depression, commitment, and work engagement. Work \& Stress: An International Journal of Work, Health \& Organisations, 22(3), 224-241. https://doi.org/10.1080/02678370802379432

Hansen, C.D., \& Andersen, J.H. (2008). Going ill to work-What personal circumstances, attitudes and work-related factors are associated with sickness presenteeism? Social Science \& Medicine, 67(6), 956-964. https://doi.org/10.1016/j.socscimed. 2008.05.022

Health Enhancement Research Organisation (HERO) (2014). White paper on: New findings and realistic solutions to employee presenteeism. Retrieved September 05 , 2015, from http://hero-health.org/wp-content/uploads/2014/03/Presenteeism_ white_paper.pdf

Hemp, P. (2004). Presenteeism: At work- but out of it. Harvard Business Review, 82(10), 49-58.

Hetland, H., Sandal, G.M., \& Johnsen, T.B. (2007). Burnout in the information technology sector: Does leadership matter? European Journal of Work and Organizational Psychology, 16(1), 58-75. https://doi.org/10.1080/13594 320601084558

Johns, G. (2010). Presenteeism in the workplace: A review and research agenda. Journal of Organizational Behavior, 31(4), 519-542. https://doi.org/10.1002/ job. 630

Joo, B.K. (2010). Organisational commitment for knowledge workers: The roles of perceived organisational learning culture, leader-member exchange quality, and
turnover intention. Human Resource Development Quarterly, 21(1), 69-85. turnover intention. Human Resource
https://doi.org/10.1002/hrdq.20031

Kanste, O., Kyngas, H., \& Nikkila, J. (2007). The relationship between multidimensional leadership and burnout among nursing staff. Journal of Nursing Management, 15(7), 731-739. https://doi.org/10.1111/j.1365-2934.2006.00741.x

Kara, D., Uysal, M., Sirgy, M.J., \& Lee, G. (2013). The effects of leadership style on employee well-being in hospitality. International Journal of Hospitality Management, 34, 9-18. https://doi.org/10.1016/j.ijhm.2013.02.001

Karlin, W.A., Brondolo, E., \& Schwartz, J. (2003). Workplace social support and ambulatory cardiovascular activity in New York City traffic agents. Psychosomatic Medicine, 65(2), 167-176. https://doi.org/10.1097/01.PSY.0000033122.09203.A3

Kouzes, J.M., \& Posner, B.Z. (1987). The leadership challenge: How to make extraordinary things happen in organisations. New York: Wiley.

Lyons, J.B., \& Schneider, T.R. (2009). The effects of leadership style on stress outcomes. The Leadership Quarterly, 20(5), 737-748. https://doi.org/10.1016/j. leaqua.2009.06.010

MacGregor, J.N., Cunningham, J.B., \& Caverley, N. (2008). Factors in absenteeism and presenteeism: Life events and health events. Management Research News, 31(8), 607-615. https://doi.org/10.1108/01409170810892163

Madlock, P.E. (2008). The link between leadership style, communicator competence, and employee satisfaction. Journal of Business Communication, 45(1), 45-61. https://doi.org/10.1177/0021943607309351

Maslach, C., \& Leiter, M.P. (2008). Early predictors of job burnout and engagement. Journal of Applied Psychology, 93(3), 498-512. https://doi.org/10.1037/00219010.93.3.498

Mathieu, C., Neumann, C.S., Hare, R.D., \& Babiak, P. (2014). A dark side of leadership: Corporate psychopathy and its influence on employee well-being and job satisfaction. Personality and Individual Differences, 59, 83-88. https://doi. org/10.1016/j.paid.2013.11.010

Matlay, H. (1999). Employee relations in small firms. Employee Relations, 21(3), 285-295. https://doi.org/10.1108/01425459910273125

McGregor, A., Iverson, D., Caputi, P., Magee, C., \& Ashbury, F. (2014). Relationship between work environment factors and presenteesim mediated by employees health. Journal of Occupational and Environmental Medicine, 56(12), 1319-1324. https://doi.org/10.1097/JOM.0000000000000263

Morrison, C.M., Chappel, T.D., \& Ellis, W.A. (1997). Age of acquisition norms for a large set of object names and their relation to adult estimates and other variables. The Quarterly Journal of Experimental Psychology, 50(3), 528-559. https://doi. org/10.1080/027249897392017 
Munir, F., Nielsen, K., \& Carneiro, I.G. (2010). Transformational leadership and depressive symptoms: A prospective study, Journal of Affective Disorders, 120(1) 235-239. https://doi.org/10.1016/j.jad.2009.03.020

Munro, L. (2007). Absenteeism and presenteeism: Possible causes and solutions. South African Radiographer, 45(1), 21-23.

Nielsen, K., Randall, R., Yarker, J., \& Brenner, S.O. (2008). The effects of transformational leadership on followers' perceived work characteristics and psychological wellbeing: A longitudinal study. An International Journal of Work, 22(1), 16-32. https://doi.org/10.1080/02678370801979430

Nielsen, K., Yarker, J., Randall, R., \& Munir, F. (2009). The mediating effects of team and self-efficacy on the relationship between transformational leadership, and job satisfaction and psychological well-being in healthcare professionals: A crosssectional questionnaire survey. International Journal of Nursing Studies, 46(9), 1236-1244. https://doi.org/10.1016/j.ijnurstu.2009.03.001

Nyberg, A., Alfredsson, L., Theorell, T., Westerlund, H., Vahtera, J., \& Kivimaki, M. (2009). Managerial leadership and ischaemic heart disease among employees: The Swedish WOLF study. Occupational and Environmental Medicine, 66(1) 51-55. https://doi.org/10.1136/oem.2008.039362

Ogbonna, E., \& Harris, L.C. (2000). Leadership style, organisational culture and performance: Empirical evidence from UK companies. International Journal of Human Resource Management, 11(4), 766-788. https://doi.org/10.1080/ 09585190050075114

Pearce, C.L. (2007). The future of leadership development: The importance of identity, multi-level approaches, self-leadership, physical fitness, shared leadership networking, creativity, emotions, spirituality and on-boarding processes. Human Resource Management Review, 17(4), 355-359. https://doi.org/10.1016/j hrmr.2007.08.006

Phillips, S., Sen, D., \& McNamee, R. (2007). Prevalence and causes of self-reported work-related stress in head teachers. Occupational Medicine, 57(5), 367-376. https://doi.org/10.1093/occmed/kqm055

Pohling, R., Buruck, G., Jungbauer, K.L., \& Leiter, M.P. (2016). Work-related factors of presenteeism: The mediating role of mental and physical health. Journal of Occupational Health Psychology, 21(2), 220-234. https://doi.org/10.1037/ accupation

Prater, T., \& Smith, K. (2011). Underlying factors contributing to presenteeism and absenteeism. Journal of Business \& Economics Research (JBER), 9(6), 1-14. https://doi.org/10.19030/jber.v9i6.4374

Prochaska, J.O., \& Prochaska, J.M. (2011). The well-being assessment for productivity. Journal of Occupational and Environmental Medicine, 53(7), 735-742. https://doi. org/10.1097/JOM.0b013e318222af48

Puig-Ribera, A., McKenna, J., Gilson, N., \& Brown, W.J. (2008). Change in work day step counts, wellbeing and job performance in Catalan University employees: A randomised controlled trail. Promotion \& Education, 15(4), 11-16. https://doi. org/10.1177/1025382308097693

Robbins, S.P., \& Coulter, M.K. (2005). Management. (8th edn.). Upper Saddle River, NJ: Pearson Prentice Hall.

Rothbard, N.P. (2001). Enriching or depleting? The dynamics of engagement in work and family roles. Administrative Science Quarterly, 46(4), 655-684. https://doi. org/10.2307/3094827
Saunders, M.N., Lewis, P., \& Thornhill, A. (2012). Research methods for business students. (6th edn.). Upper Saddle River, NJ: Financial Times/Prentice Hall.

Schaufeli, W.B., Salanova, M., Gonźalez-Roma, V., \& Bakker, A.B. (2002). The measurement of engagement and burnout: A two-sample confirmatory facto analytic approach. Journal of Happiness Studies, 3(1), 71-92. https://doi.

Schaufeli, W.B., Taris, T.W., \& van Rhenen, W. (2008). Workaholism, burnout, and work engagement: Three of a kind or three different kinds of employee well-being? Applied Psychology: An International Review, 57(2), 173-203. https://doi. org/10.1111/j.1464-0597.2007.00285.x

Scheepers, C., \& Shuping, J. (2011). The effect of human resource practices on psychological contracts at an iron ore mining company in South Africa. SA Journal of Human Resource Management, 9(1), 1-19. https://doi.org/10.4102/sajhrm.v9i1.302

Skakon, J., Nielsen, K., Borg, V., \& Guzman, J. (2010). Are leaders' well being, behaviours and style assoicated with the affective well-being of their employees? A systematic review of three decades of research. Work \& Stress: An Internationa Journal of Work, Health \& Organisations, 24(2), 107-139. https://doi.org/10.108 0/02678373.2010.495262

Skogstad, A., Einarsen, S., Torsheim, T., Assland, M.S., \& Hetland, H. (2007). The destructiveness of laissez-faire leadership behavior. Journal of Occupational Health Psychology, 12(1), 80. https://doi.org/10.1037/1076-8998.12.1.80

Sosik, J.J., \& Godshalk, V.M. (2000). Leadership styles, mentoring functions received, and job related stress: A conceptual model and preliminary study. Journal of Organizational Behavior, 21(4), 365-390. https://doi.org/10.1002/(SICl)10991379(200006)21:4<365::AID-JOB14>3.0.CO;2-H

Tarafdar, M., Tu, Q., Ragu-Nathan, B.S., \& Ragu-Nathan, T.S. (2007). The impact of technostress on role stress and productivity. Journal of Management Information Systems, 24(1), 301-328. https://doi.org/10.2753/MIS0742-1222240109/

Vinger, G., \& Cilliers, F. (2006). Effective transformational leadership behaviours for managing change. South African Journal of Human Resource Management, 4(2), 1-9. https://doi.org/10.4102/sajhrm.v4i2.87

Whitehouse, D. (2005). Workplace presenteeism: How behavioral professionals can make a difference. Behavioral Healthcare Tomorrow, 14(1), 32-35.

Wolfram, H.J., \& Mohr, G. (2009). Transformational leadership, team goal fulfillment, and follower work satisfaction: The moderating effects of deep-level similarity in leadership dyads. Journal of Leadership \& Organisational Studies, 15(3), 260-274. https://doi.org/10.1177/1548051808326595

Yang, L.R., Huang, C.F., \& Wu, K.S. (2011). The association among project manager's leadership style, teamwork and project success. Internatic Journal of Project Management, 29(3), 258-267. https://doi.org/10.1016/j. ijproman.2010.03.006

Zikmund, G.W., Babin, B.J., Carr, J.C., \& Griffin, M. (2009). Business research methods. (8th edn.). Mason, $\mathrm{OH}$ : South-Western Cengage Learning.

Zikmund, W.G. (2003). Business research methods. (7th edn.). Cincinnati, $\mathrm{OH}$ Thomson/South-Western

Zopiatis, A., \& Constanti, P. (2010). Leadership styles and burnout: Is there an association? International Journal of Contemporary Hospitality, 22(3), 300-320. https://doi.org/10.1108/09596111011035927 